\title{
Seafarer's Stress and Long Distance Relationship with Family
}

\author{
Hendro Prabowo, Firda F. Fatimah, Alia R. Fauziah, Ira N. Prabawati, and Maria Chrisnatalia
}

\begin{abstract}
The purpose of this research is to know the work pressure faced by modern Indonesian seafarers and their long distance relationship with their family. Five seafarers who originally lived in Jakarta participated in this qualitative study. Data were gathered through interviews by mobile phone. Thematic content analysis identified themes and sub-themes, among others: stress related to work, stress related to family, stress related to worship, stressor related to catastrophe, how to cope the stress, and optimal sailing interval. Some implications for theoretical and practical consideration were discussed.
\end{abstract}

Index Terms - stress, stressor, coping, seafarer, Indonesia.

\section{INTRODUCTION}

$\mathbf{R}$ adha [1] describes the seafarers and their activities as follows: "These ships differed not only in size and the number of their masts, but also in the number and shape of their sails, and their ropes-that their rigging. And it took long experience for a sailors to know all these points, the names and uses of the hundreds of different ropes, and the dozens of different sails and how furl and unfurl them, and when".

"The sailor too, had to know the sings of the weather so that the he might know when-storms were coming; and he had to study the charts and to know where it was safe to gothough this part of the work was the job of the captain and offices more than that of the common sailors. Nowadays the chief workers on a steamer are the engineers; the 'sailors; have no rigging or sails to attend to, and so are not sailors in the old sense, though there are still ships in use".

"A sailor's life is a hard rough one; and it is dangerous. We landsmen have little idea what it must be to climb the tall masts in a storm to furl the sails, when the ship is rolling and pitching like a mad thing, the wind is icy cold, the rain is pouring down, and it is pitch dark. And sailors are always in

Hendro Prabowo is with the Faculty of Psychology, Gunadarma University, Depok, West Java, Indonesia (e-mail: ndrahu@yahoo.com).

Firda F. Fatimah is with Faculty of Psychology, Gunadarma University, Depok, West Java, Indonesia

Alia R. Fauziah is with Faculty of Psychology, Gunadarma University, Depok, West Java, Indonesia

Ira N Prabawati is with Faculty of Psychology, Gunadarma University, Depok, West Java, Indonesia

Maria Chrisnatalia is with Faculty of Psychology, Gunadarma University, Depok, West Java, Indonesia danger of shipwreck or sinking in a storm, of fire, or of dying of thirst in calm".

Actually, the description by Radha above is not much different from what [2] described about seafarer two centuries ago, especially in the face of danger, storms, weather, and death. On the other hand, according to Thomas [14] the dependence on intimate partnerships and immediate family as a support system may be particularly important for seafarers who are an extremely socially isolated group. Therefore, in the digital age there are a lot of information on the internet about long distance relationship between seafarer and his family. A life is different from common family because seafarers live separated for long periods with their family.

Indonesia is most archipelago country in the world, where $75 \%$ of the territory is the sea, it is very necessary to have many seafarers, both traditional and modern. In 2016 the Indonesian government tried to make Indonesia a strong Maritime Country and as a World Maritime Axis. This proved to be quite successful, while the Indonesian merchant fleet grew significantly by $132.8 \%$ or about 15 thousand units in the last 10 years $(2005$ - 2015) [4]. The purpose of this research is to know the work pressure faced by modern Indonesian seafarer and long distance relationship with their family.

\section{MEthods}

Five seafarers who originally lived in Jakarta participated in this qualitative study. Data were gathered through long distance chat interviews by gadget or mobile phone. These five participants described demographically in Table 1.

TABLE 1.

DEMOGRAPHIC OF PARTICIPANTS

\begin{tabular}{cccccc}
\hline $\begin{array}{c}\text { Initial } \\
\text { Age }\end{array}$ & Status & $\begin{array}{c}\text { Sailing } \\
\text { Experien } \\
\text { ce }\end{array}$ & $\begin{array}{c}\text { Main } \\
\text { Job }\end{array}$ & Sailing Route & $\begin{array}{c}\text { Type of } \\
\text { Ship }\end{array}$ \\
\hline A (27) & Single & 1 year & Chef & International & Cruise \\
B (34) & Single & 16 year & Crew & International & LNG \\
NGM (28) Engagement 3 years & $\begin{array}{c}\text { Chef } \\
\text { International }\end{array}$ & Cruise \\
GSK (26) & Single & 5 year & $\begin{array}{c}\text { Depart } \\
\text { ment of International } \\
\text { Deck } \\
\text { Container }\end{array}$ \\
L (20) & Dating & 1,5 year $\begin{array}{c}\text { Apprent } \\
\text { ice }\end{array}$ & Domestic & Cargo \\
\hline
\end{tabular}

A qualitative approach was adopted to capture a deep understanding of the meaning of experiences through 
insightful descriptions of the experience under investigation, as presented through the participant's narratives and explanations [5]. Thematic content analysis was performed by identifying and coding themes and sub-themes across cases.

\section{FINDINGS}

Analysis of the results revealed that the essence of work pressure and long distance relationship stems from six main themes and several sub-themes.

\section{A. Stress related work}

In general, stress related to the work beside the job itself is about crewing. This work stress produces stress symptoms such as sleep disorders and fatigue. Crewing problems experienced by GSK and L. GSK have language obstacles because different citizenships and age difference between superiors and subordinates. While L feels the need to deal with many different characters of the co-worker. "... some are hard, some are soft, some are painful behind”. Similar with L, for A people's habits in each country is different.

As a Chef serving thousands of guests on cruise, each year A can get a different ship than before. And when he first came on the new ship he was asked by his boss, what section on the previous ship. If lucky he can get the same section with the previous ship. If not, then he gets a new section and has to learn something new.

As a result of the pressure of work, sleep disturbance is experienced by L, because the rest is less and is also done on ship. NGM must stay up late to communicate with his family after working hours due to the time difference.

TABLE 2.

THEMES AND SUB-THEMES

\begin{tabular}{cc}
\hline Themes & Sub-themes \\
\hline Stress related work & crewing, sleep, and fatigue \\
Stress related to & miss, worried, psychological \\
family & impact \\
Stress related to & adzan, qibla, prayer, fasting, \\
worship & celebrate Eid Al-Fitr \\
Stressor related to & myth, disaster \\
catastrophe & video calls, chat, send photos, \\
How to cope the & display photos, watching TV \\
stress & and recreation \\
Optimal sailing & 6 month \\
interval &
\end{tabular}

\section{B. Stress related to family}

Generally, stress related to the family is miss, especially on $\mathrm{B}, \mathrm{NGM}$ and L. In addition, there is a sense of worry with families, especially on A, B, and NGM. A miss his family just when there is job pressure. B feels miss with her parents, relatives, and friends at home. NGM felt pressured because he, three times, did not celebrate Eid with the family. The sense of missed with family also experienced by NGM, and how to cope it is with video calls, chat, send photos, and display photos in the cabin.

When faced with a storm, NGM revealed: "... there was a sense of worry ... can I see my family again or not?. NGM also felt: "...there is something at home, for example when parent illness or something. Sometimes we are so confused, worry about how far away... ". Meanwhile, the family of GSK worry about him, "From my own family, they always worried about whether no news about me or wondered when I come home, especially if there are bad weather reports, sunken ships, etc. Anyway related to the sea that the news is not good, my family must immediately call and wonder. In fact, I was asked to work just on land". L just tells the good and bad when at home, if through chat, L was afraid to make his family worried.

For the GSK does not meet the family for a long time is one cause of decreased performance, work accidents, and human error. The other psychological impacts for GSK and NGM are afraid to get married because to decide to marry need more considerations. For GSK, this is due to two things. First, his subjective experience when dating. His girlfriend often protest because of busy work, difficult communication cause of lack of signal, and rarely meet directly. Second, the experience of other seafarers who oftenly feel dizzy because they miss with their children and wives. Many seafarers whose families were destroyed by husbands rarely returned home and partner infidelity. NGM questioned herself, "If I decided to marry, I will hard to think whether going to sea or not ... ".

\section{Stress related to worship}

Since most of the participants are Muslims, the activity of sea can become an obstacle to worship, particularly prayer and fasting. B is one participant who can worship pray well on the ship. Otherwise, it is not easy for other participants.

A feels his worship sometimes becomes hard to do. A also miss the sound of the call to prayer, while the call prayers that are not found on the ship when shipping. It is not easy for $L$ to determine the direction of the Qibla for prayer. NGM and GSK feel pressured because never fasting and celebrating Eid Al-Fitr with family. A uses the compass to determine the direction of Qibla and B installs the prayer time application on handphone.

L who missed the family and how to overcome it is to ask the captain's permission to go home for 3 days when the ship anchored in Jakarta. This permission does not always work for L, because sometimes the captain insists on not giving permission to go home. If there is permission, it will be done alternately with other crew.

\section{Stressor related to catastrophe}

Participants must face the other source of stress, stress from nature including myth and disaster. Not all participants sailed through a mysterious route with many myths, both domestic and international routes. GSK says about the myth in the waters of Masalembo (between Java and Kalimantan) that there were many emergency events in this area, so equating 
this region as the Bermuda triangle of Indonesia. But based on his experience, in this area he felt nothing.

"I do not know why many ship accidents in Indonesia were in Masalembo. The case of a shipwreck is also a lot in Masalembo .... The other side of the Masalembo myth is much associated with its Indonesian triangle, where in America is called Bermuda triangle".

"I often pass through the Masalembo, but Alhamdulillah never felt anything, and if I am passing through there also nothing, I feel like usual, there are no superstition rituals of any kind, just like through to the other waters".

As for the NGM who has an international route, when passing through the Bermuda triangle, he feels this region is not mysterious but an only natural phenomenon and often a bad weather. "... my ship line in the Caribbean .. it pass through the Bermuda triangle. Actually it's not a mystery ... because of the natural phenomenon ... and often bad weather".

Beside the myth, participants also experienced another catastrophe in the sea. B feels anxious when the wave season, because the ship swayed. L had experienced his ship hit by waves and conceded for 3 days. "... ever until the ship leakages.... flooding on the deck, until the ship is tilted leftright ... just irregular, until the ship was tilted 15 degrees .... "

For NGM, the most uncomfortable thing is when facing a storm in the middle of the sea, especially in Bermuda. He once trapped three hurricanes in the middle of the sea, when all the ports to be visited were destroyed so the ship could not be anchored. As a result, his return home was delayed for two weeks.

\section{E. How to cope the stress}

$\mathrm{B}$ is the most fortunate participants because he can easily worship to cope his saturation. In addition, working hours are also similar to office hours in general, ie from 8:00 until 4:30 $\mathrm{pm}$. His ship also has many facilities for coping stress, such as a gathering place for crew, games, band set, fitness, and smoking room. "Yes, gathered together with friends ... There is crew playing PS (play station). Some crew are playing band .. There are some crews in the fitness room... get together with my friends ... in the smooking room".

GSK copes his saturation by watching TV and recreation when the ship is anchored. Both GSK and NSK, they have a similar way of viewing family photos and calling home (video call or chat). To make a phone call can be done only when there is a signal and sometimes also have to stay up.

\section{F. Optimal sailing interval}

The distance between sea and land is not an easy issue for seafarers. Company policy also varies in applying the right time span. A claimed is at sea for 8-10 months and on land for vacation or return home for 2 months. B goes to sea for 6 months and go home for 6 months. Previosly NGM sailed in a year, a longest period for him, now 9-10 months, while vacation at home only 1 month.

For GSK, going to sea for 9 months and vacation only for 1 month, so he felt uncomfortable on the ship. If the ship anchored in Jakarta, GSK can get an extra vacation at home for a few days. "... if the contract from the company is at least 9 months, but my ship entered Jakarta yesterday, oftenly .., so it also depends on the port of destination... Well just now because of the number of seafarers who do not stay in the ship until 9 months, now many shipping companies change to 6 months contract". Since it is still an apprentice, $\mathrm{L}$ should go to sea for 1.5 years and only 2 months of vacation, although occasionally can go home several days if his ship is anchored in Jakarta, just like GSK.

\section{DISCUSSION}

The results of this research on stress and family relationship on the Indonesian seafarer support some previous research, which have been done to seafarer from other countries.

Thomas [3] found that social isolation was found to be a significant issue for seafarers. Changes in crewing patterns meant that relationships at sea were often limited to 'onboard acquaintances', and, where relationships did develop, geographical separations and unsynchronised leave periods made the maintenance of these relationships problematic. Rengamani, Murugan, \& Sakthivel [6] also revealed that the long working days, heat in work places, separation from their family, time pressure/ hectic activities, and insufficient qualifications of subordinate crew members are the most important stressors on board. The seafarers with higher stress due to heat in shipboard operations had shorter job duration at sea.

Panganiban and Garcia [7] discovered that Filipino seafarers find contributory factors relating to stress and weariness to be moderately significant to which physical factors prevail over emotional, environmental and psychological. On the other hand, the significant difference is still found when talking of responses on the environmental, emotional, physical and psychological factors contributory to stress and weariness of Filipino seafarers. Thiruvasagam \& Rengamani's study [8] also concluded that weariness factors that Indian seafarers go through, including the long working hours, irregular sleep patterns, frequent adaptations in the maritime industry, environmental challenges, improper exercises and nutrition.

Thomas, Sampson, \& Zhao [14] stated that separation from family and partner has been one of the most significant causes of stress. Plopa [9] claimed that family may constitute a significance of both the quality of a seafarer's functioning and personal costs he would experience in long-term stress conditions. Tang [15] stated that a group of seafarer-partners made use of cyberspace in order to cope with long-term waiting and temporal disruption to their relationships caused by seafarer's working patterns. Information, experience, and stories are shared to manage stress, resulting in strengthening their relationships despite the time consumption. Study of Thomas [3] discovered frequent communication eased and ensured that the seafarer still holds a role within the family whether at sea or land. Couples reported their means of communication, ranging from satellite phone calls to letters, mobile telephone calls to email. 
In accordance to Foster \& Cacioppe [10], not a small number of women (Australian seafarer's partners) felt that their partner's life caused challenges in their marriage, and 25 $\%$ of the wives believed that their husbands had or were having sexual relations with other women.

Thomas [3] stated that transitions between ship and shore were reported to be the most challenging period of the work cycle as seafarers struggled in adjusting to shore life. Seafarers reported taking their time to recover from the stress relating to their shipboard life, and many reported to be struggling to adjust the proper sleeping patterns to fit in with those of their families. Thomas, Sampson, \& Zhao [14] concludes that such policies as shorter trips, continuous employment (rather than employment by voyage) and opportunities for partners and families to sail can minimize consequences of seafaring. Thus, in promoting seafarer-partner relationship, Thomas [3] suggests that working rather relatively in short tours of duty (for example, not longer than one or two months) to make the couples result in a more positive experience to manage seafaring lifestyle.

Cochran-Smith [11] stated that the legend of the triangular area in the Atlantic Ocean, more precisely at Puerto Rico, Bermuda, and Miami, where countless people and more than 70 sea and air crafts have disappeared without a trace during the last half-century. But, he asserted there are no unexplainable disappearances, no Bermuda Triangle, and no mystery to solve. The "mystery" of the Bermuda Triangle starts as the headline story in a fiction magazine, has been popularized in articles, best-sellers, and television documentaries. In the domestic route, the frequent of the ship where accidents in the sea of Masalembo were particularly caused by the ocean wave. In December - February, due to the effects by both West Monson and Arlindo ocean wave from the Northern Hemisphere, and in July to September due to effects only by Arlindo ocean currents from the Southern Hemisphere. If it is proven that the Masalembo Triangle is causing many disruptions toward sea and air transportation, it is necessary that more sophisticated sea and air traffic signs be inserted at this location, avoiding the mystical belief [12].

Facing catastophe at sea is no strange thing to seafarers. At this century, hurricane incidents tend to increase globally. As to what have been stated by Webster, Holland, Curry, \& Chang [13], hurricanes that are categorized from 1 to 5 (SaffirSimpson scale) are defined as storms with certain wind speeds. Webster et al. [13] define the ocean basins supporting tropical cyclone development are as follows: North Atlantic, western North Pacific, eastern North Pacific, South Indian, North Indian, and Southwest Pacific. On the other hand, the sum of hurricane categories 2 and 3 are both small in number. In contrast, hurricanes that are in the strongest categories (4 and 5) have more than likely to double in number. The spike in category 4 and 5 hurricanes has not been summed with the increase in the actual intensity of the most intense hurricanes.

\section{CONCLUSION}

The meaning of seafarer's stress and long distance relationship with family among other: stress related to work, stress related to family, stress related to worship, stressor related to catastrophe, how to cope the stress, and optimal sailing interval.

\section{RECOMMENDATION}

For the further researcher, this research recommends to develop:

1. More research participant

2. Using in-depth interviews and participant observation

3. Using a quantitative approach to correlate some types of stress (work, family, worship, and catasthrope) and coping stress with seafarer performance.

For shipping companies, this research recommends to develop:

1. Various facilities on the ship for coping stress and worship.

2. Predictability of seafarers' work schedules so that seafarer's arrival and departure from home can be more accurately anticipated. Including celebrating religious holidays.

3. Predictability of seafarers' crewing, if possible facilitating seafarers sail with same crew and same job.

4. Communication between seafarers and family, both quantity and various method.

\section{ACKNOWLEDGMENT}

This research was partially supported by Mahargyantari P. Dewi, who has facilitated the meeting in her home. We thank our colleague from Purwantono who provided experience and expertise in seafarer education that greatly assisted the idea of the research.

\section{REFERENCES}

1. M. Radha, "A sailor's life is a hard and rough one; and it is dangerous," boddunan.com. 2011.

2. R. M. Dana, "Two years before the mast: A personal narrative of life at sea," Modern library, 1840.

3. M. Thomas, "Lost at sea and lost at home: The predicament of seafaring families," Seafarers International Research Centre, Cardiff University, 2003.

4. Unity of Indonesian Seafarer, "Marine and marine axis programs must enter the GBHN,"

http://www.kpiunion.org/berita-program-poros-maritim-tol-laut-harus- masuk-gbhn.html\#ixzz5GcBmS7 Fc. 2016.

5. C.E. Moustakas, Phenomenological Research Methods, Sage, Thousand Oaks, California, 1994.

6. J. Rengamani, M. Murugan, and Sakthivel, "A study on the factors influencing the seafarers' stress," AMET International Journal of Management, 4, pp. 44-51, 2012.

7. A.U. Panganiban, and O.B. Garcia, "Contributory to Stress and Fatigue of Filipino Seafarers," Asia Pacific Journal of Maritime Education, 3. pp. 1-14, 2017.

8. G. Thiruvasagam, and J. Rengamani, "Seafarers fatigue management-an empirical study on Indian seafarers," Journal of Management, 6, pp. 35-47, 2015.

9. M. Plopa, "Psychological Studies of Stress Experienced by Seamen During a Long-Distance Sea Voyage, in M. Plopa," Stress in Sea Isolation: Psychosocial Predictors. University of Gdańsk Press, Gdańsk, pp. 247- 259. 2005. 
10. D. Foster, and R. Cacioppe, "When his ship comes home: The stress of the Australian seafarer's partner," Australian and New Zealand Journal of Family Therapy, 7, pp. 7581, 1986.

11. M. Cochran-Smith, "Teacher education's Bermuda Triangle: Dichotomy, mythology, and amnesia," Journal of Teacher Education, 54, pp. 275-279, 2003.

12. M. Chaeran, and Harcici, "Misteri segitiga "Masalembo" merupakan segitiga Bermuda di wilayah Indoesia,"Jurnal Sains dan Teknologi Maritim, 2, pp. 122-131, 2017.

13. P.J. Webster, J.H. Greg, A.C. Judith, and H-R. Chang, "Changes in tropical cyclone number, duration, and intensity in a warming environment," Science 309, 5742, pp. 1844-1846, 2005.

14. M. Thomas, H. Sampson, and M. Zhao, "Finding a balance: companies, seafarers and family life," Maritime Policy \& Management, 30, pp. 59-76, 2003.

15. L. Tang, "Waiting together: Seafarer-partners in cyberspace,"Time \& society, 21, pp. 223-240, 2012. 